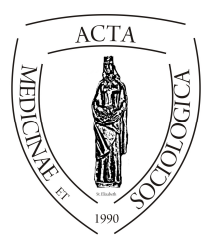

\title{
Globalizáció, lokalizáció és individualizáció nyíregyházi középiskolások körében ${ }^{1}$
}

\author{
Kovács Klára ${ }^{1}$, Ludescher Gabriella ${ }^{2}$, Dusa Ágnes Réka ${ }^{3}$ \\ 1. adjunktus, Debreceni Egyetem BTK, 4032 Debrecen, Egyetem tér 1., kovacs.klara@arts.unideb.hu. \\ 2. adjunktus, Debreceni Egyetem Egészségügyi Kar, Szociális és Társadalomtudományi Intézet, 4400 Nyíregyháza, \\ Sóstói út 2-4. ludescher.gabriella@foh.unideb.hu \\ 3. kutató, Debreceni Egyetem BTK, 4032 Debrecen, Egyetem tér 1., dusa.agnes@arts.unideb.hu.
}

\begin{tabular}{ll}
\hline \multicolumn{1}{c}{ INFO } & \multicolumn{1}{c}{ ABSTRACT } \\
\hline $\begin{array}{l}\text { Klára Kovács } \\
\text { kovacs.klara@arts.unideb.hu. }\end{array}$ & $\begin{array}{l}\text { Globalization, Localization and Individualization among } \\
\text { High School Students in Nyíregyháza. In the first part of our } \\
\text { study we examined the attitude of the high school students of } \\
\text { Nyíregyháza to international mobility, with special attention to } \\
\text { cross border mobility, } \\
\text { locality, } \\
\text { the neighbouring countries and different ethnic groups. In } \\
\text { connection with that, we also wished to find out about the } \\
\text { satisfaction with life } \\
\text { relationship of the young people to their own region, how } \\
\text { powerful their local consciousness is, and what chances in life } \\
\text { they envisage. Their international experience and plans, their } \\
\text { bonds to their respective region are examined in interrelation. } \\
\text { In the second part of the study we concentrate on the } \\
\text { international experience of the students related to crossing the } \\
\text { borders: how much they have travelled and for what reasons, } \\
\text { would they like to study and/or live abroad, and what factors } \\
\text { influence these plans. In part three of the study we examine } \\
\text { some of the characteristics of the life of the secondary school } \\
\text { students of Nyíregyháza at an individual level: the patterns of } \\
\text { their leisure activities, their satisfaction with their own life and } \\
\text { well-being. Our survey is based upon the data base of an } \\
\text { inventory research conducted among 11th grade (senior high } \\
\text { school) students in 2015. Locality and regionality play an } \\
\text { important role in the life of these students, but their personal } \\
\text { relationships reach beyond the national borders. It is clearly } \\
\text { seen from the results that students coming from a higher socio- } \\
\text { economic status have had more opportunities to travel abroad. } \\
\text { Their free time is dominated by social solitude, whereas their } \\
\text { satisfaction with life is largely influenced by their social } \\
\text { activities and their subjective social situation. }\end{array}$ \\
\hline
\end{tabular}

\footnotetext{
${ }^{1}$ A tanulmányt a Bolyai János Kutatói ösztöndíj támogatta (2016-2019).
} 


\author{
Kulcsszavak \\ külföldi mobilitás, \\ lokalitás, \\ szabadidö, \\ élettel való elégedettség
}

\begin{abstract}
Absztrakt: Tanulmányunk első részében azt vizsgáljuk, hogy miként gondolkodnak a nyíregyházi középiskolások a külföldi mobilitással kapcsolatban, különös tekintettel a szomszédos országokhoz, illetve a más nemzetiségekhez füződő viszonyra. Ehhez kapcsolódóan arra is kíváncsiak voltuk, hogy saját régiójukhoz hogyan viszonyulnak a fiatalok, mennyire erős a lokális-tudatuk, s milyen életesélyeket látnak itt a maguk számára. A külföldi tapasztalatokat és terveket, a lokális, regionális kötődést egymáshoz viszonyítva is vizsgáljuk. A tanulmány második részében a fiatalok határátlépéssel járó nemzetközi mobilitási tapasztalatait és terveit vizsgáljuk meg: mennyit utaznak és milyen okból, szeretnének-e külföldön tanulni, külföldön élni, ha igen hol, s mik befolyásolják ezeket a terveket. A tanulmány harmadik részében egyéni szinten nézzük meg a nyíregyházi középiskolások jellemzőit: a szabadidős tevékenységeik mintázatát és élettel való elégedettségüket mint életmódhoz és jólléthez kapcsolódó individuális tényezőket vizsgáljuk meg körükben. Kutatásunkhoz egy 2015-ben, nyíregyházi 11. évfolyamosok körében végzett kérdőíves felmérés adatbázisát használtuk fel. A lokalitás és regionalitás fontos szerepet játszik a fiatalok életében, de kapcsolataik átnyúlnak az ország határain túlra. Ugyanakkor azt is láthatjuk, hogy a magasabb szocio-ökonómiai státuszú fiatalok jártak már többször külföldön. A szabadidö-eltöltésben a társas magány dominál, viszont az élettel való elégedettséget a társas tevékenységek befolyásolják, akárcsak a szubjektív társadalmi helyzet.
\end{abstract}

\section{Bevezetés}

A határmenti települések sajátos település-földrajzi, gazdasági, kulturális, szociológiai, oktatási térségeket alkotnak (Süli-Zakar 2010) - gyakran perifériális helyzetü térséget (Ilyés 2004). Hardi definíciója szerint ,,azt tekinthetjük határ menti térségnek, amelynek mindennapi életét alapvetően befolyásolják a szomszédos határtérséggel fenntartott interakciók" (Hardi 2008:4). A határ menti régiókat ráadásul úgy is felfoghatjuk, mint egyfajta átmeneti szint: egyrészről megszürik a globális jelenségeket a lokális színtér és az egyén számára, másrészt összegyüjti a lokális és individuális jelenségeket, folyamatokat, attitüdöket (Süli-Zakar 2010).

Éppen ezért lehet érdekes megvizsgálni, hogy egy ilyen sajátos, államhatárhoz közeli magyar város, Nyíregyháza fiatalságára (11. évfolyamos középiskolai diákjaira) mennyire jellemző a regionalitás, s hogy e diákok mennyire kötődnek lokális, regionális szinten, vagy éppen mennyire mobilisak regionális vagy nemzetközi, globális szinten. Mind a lokális, regionális kötődés egyfajta beilleszkedést, csoporthoz való tartozást jelez - ezért az individualizáció szempontjából is érdemes megvizsgálni a fiatalokat. Utóbbi jelenséget a szabadidő-eltöltésen és jólléten keresztül közelítettük meg. Tanulmányunk első részében azt vizsgáljuk, hogy saját régiójukhoz hogyan viszonyulnak a fiatalok, mennyire erős a lokális-tudatuk, s milyen életesélyeket látnak itt a 
maguk számára. A külföldi tapasztalatokat és terveket, a lokális, regionális kötődést egymáshoz viszonyítva is vizsgáljuk. A tanulmányunk második része a külföldi mobilitási tapasztalatokra és tervekre koncentrál, s arra keresi a választ, hogy a nyíregyházi fiatalok mennyit utaznak a régión belül, de a határokat átlépve, valamint menynyire nyitottak jövőterveiket tekintve a külföldi tanulás, külföldi munkavállalás iránt. A globalitás egy szemlélet, a nemzetköziesedés iránti nyitottság, de akár a társadalmitávolság kifejezése is lehet, ezért felmértük a diákok szimpátiáját a szomszédos országok és más nemzetek iránt. A tanulmány harmadik részében egyéni szinten nézzük meg a nyíregyházi középiskolások jellemzőit: a szabadidős tevékenységeik mintázatát és élettel való elégedettségüket mint életmódhoz és jólléthez kapcsolódó individuális tényezőket vizsgáljuk meg körükben.

\section{Minta és módszerek}

A tanulmány alapját képező kérdőíves adatfelvételre 2015 május-júniusában került sor. A kutatás egy nemzetközi projekt keretében valósult meg (Youth in the Central and Eastern European Cross-border Areas), melyben a lengyel, ukrán és magyar határ menti térség egy-egy nagyvárosban élö, érettségi előtt álló középiskolás fiatalokat kérdeztek meg. Ezért esett a választásunk Nyíregyháza városára. Kutatás célja az e térségben élő fiatalok tanuláshoz, munkához kapcsolódó jövőképének, életcéljainak, külföldhöz és régiójukhoz kapcsolódó attitüdeinek, életmódjának és társadalmi hátterének feltérképezése volt. Mivel érettségi előtt álló középiskolásokat kérdeztünk meg, ezért szakközépiskolákat és gimnáziumokat kerestünk fel. Öt intézmény (két gimnázium és három szakközépiskola) 359 11. évfolyamos diákja töltötte ki a kérdőívet, közülük 132 fő szakközépiskolás, 201 fő gimnazista volt, 26 fő pedig nem jelölte meg intézménye típusát. Az elemszám kijelölésénél azt vettük figyelembe, hogy minden országban körülbelül hasonló mintanagyság legyen. A Közoktatási Információs Iroda adatszolgáltatása alapján csoportos, rétegzett mintavételt alkalmaztunk: mindkét iskolatípus esetében mintegy $18 \%$-os mintát vettünk.

A legfontosabb alapstatisztikák ismertetése után varianciaelemzéssel és khí-négyzet próbával nézzük meg a legfontosabb társadalmi háttérváltozók (nem, lakóhely településtípusa, szülők iskolai végzettsége, munkaerő-piaci státusza és beosztása, objektív és szubjektív anyagi helyzet ${ }^{2}$ ) hatását a vizsgált kérdéskörökben. Az eredményeket összehasonlítottuk a Magyar Ifjúság 2012 (Székely és Nagy 2013) és az ez alapján készült

\footnotetext{
${ }^{2}$ Objektív anyagi helyzet kérdése: Az alább felsoroltakból, kérjük, jelölje meg, melyekkel rendelkezik az Ön családja: 1. Mosogatógép, 2. Mobiltelefon, 3. Plazma, LCD vagy LED TV, 4. Számitógép, 5. NoteBook vagy NetBook, 6. Nyaraló, 7. Személyautó, 8. Állandó internet-hozzáférés, 9. Tanuláshoz használt asztal, 10. saját szoba. A szubjektív anyagi helyzet kérdése: Jelölje meg, az alábbiakban felsorolt válaszok közül melyik mutatja legjobban az Ön családja anyagi helyzetét? 1. Nagyon szegényen élünk, még az alapvetö szükségletekre sem jut elég pénz; 2. Szerényen élünk, minden napot ki kell gazdálkodni; 3. Közepesen élünk, elegendö pénzünk van a mindennapi szükségletekre, de drágább dolgokra már nem jut; 4. Elégjól élünk, jut mindenre; 5. Másokhoz viszonyitva mi nagyon jól élünk, luxus dolgokat vagy megtakaritást is megengedhetünk magunknak
} 
Nyíregyháza ifjúsága 2015 (Huszti, Hüse és Takács 2016) kutatás eredményeivel, melyekben 15-29 éves fiatalokat vizsgáltak az általunk érintett kérdéskörökben is.

\section{Lokális és regionális identitás jellemzői}

Az 1990-es évek óta végbement területi történések, mint például a határok szabad átjárása, a régiók felülről vezérelt „megszületése” és az Európai Unió közösségéhez való csatlakozás olyan változásokat hozott, melyek lassan beépültek az emberek mindennapi életébe. Társadalmunk fiatal korosztálya beleszületett e változásokba, így természetes számukra a régió fogalma és a határokon való szabad mozgás. A kutatások (Egedy 1996; Ristić, Nagy és Kicošev 2013) azt bizonyítják, hogy fiatalok a településüket, a régiójukat, az országukat, a szomszédos országokat és Európát elsősorban emocionális alapon értékelik. A regionális tudomány szakirodalma (Somlyódiné Pfeil 2007, Palkó 2009, Murányi és Szoboszlai 2000, Nárai 2009, Paasi 1989, Ludescher 2009) több évtizede foglalkozik területi identitástudattal, a lokalitás vizsgálatával, ugyanakkor az empirikus vizsgálatokban kis számban jelenik meg (Ristić et al. 2013, Egedy 1996) a fiatalok lokális identitástudatának vizsgálata. Fontos lenne e témára a szakmának jobban fokuszálni, mert a különböző helyek és terek, amelyekben a fiatalok élnek, befolyásolják, alakítják az identitásukat. A társadalmi terekkel foglalkozó elméletek többségének egyik alapvető feltevése, hogy a térbeliség a társadalmi tevékenység fontos dimenziója. A teret értelmezhetjük olyan kontextusként, amelyben a társadalmi élet zajlik, a tér ugyanakkor a társadalmi élet lenyomata is (Strassoldo 1990).

Az elvárások mérése, melyek a jövő felé irányulnak, alkalmasak a regionális öntudat mérésére. Így a nyíregyházi térséghez való viszonyulás témakörét elsőként a kérdőives vizsgálatunk úgy operacionalizálta, hogy rákérdezett a véleményükre: szerintük a régiójukban a fiataloknak van-e lehetősége elérni céljaikat. A megkérdezettek közel fele $(47,9 \%)$ a van is, meg nincs is választ adta, $8,9 \%$-a a nincs választ jelölte meg, 13,9\%a az inkább nincs, míg a megkérdezettek $15,9 \%$-a igen, van és $10,6 \%$-a inkább van választ adta. Látható, hogy a megkérdezettek több mint egynegyede pozitívan látja a lehetőségét a régióban és a megkérdezettek közel fele tendál a „van is, meg nincs is lehetöség a célok elérésére" válaszra. A nemek között nincs szignifikáns különbség.

Ristić és munkatársai (2013) kutatása szerint a hely fogalmához gyakran kötődnek közösségekről alkotott elgondolások és képzetek, ugyanakkor a helyek nem jelentenek szükségszerủen közösségeket, habár elősegíthetik a közösség kialakulását. A nyíregyházi kutatás az említett kutatáshoz hasonlóan a közösségekre kérdezett rá, melyet a különböző terekkel, területi nagyságokkal köt össze. Így a diákok kapcsolatát különbözö közösségekkel (mint pl. az ország állampolgáraival, családdal, városával, megyéjével, régiójával, stb.), zárt kérdésekkel tudakoltuk. A közösség fontosságát négyfokú skálán értékelhették, arra is lehetőségük volt, hogy egyik felkínált közösséget se értékeljék, ha azzal kapcsolatban semmit sem gondoltak, illetve nem akartak válaszolni (1. táblázat). 


\begin{tabular}{|l|c|c|c|c|c|}
\hline & $\begin{array}{c}\text { Nagyon } \\
\text { erős }\end{array}$ & Erős & Gyenge & $\begin{array}{c}\text { Egyáltalán nem } \\
\text { érzem }\end{array}$ & $\begin{array}{c}\text { Nem tudom/nem } \\
\text { válaszolok }\end{array}$ \\
\hline Országa állampolgáraival & 3,6 & 22,8 & 42,3 & 17,3 & 13,9 \\
\hline Családdal & 63 & 29 & 5,8 & 0 & 2,2 \\
\hline $\begin{array}{l}\text { Városával (falujával), } \\
\text { ahol él }\end{array}$ & 7,2 & 35,1 & 40,1 & 10,3 & 7,2 \\
\hline Megyéjével & 2,2 & 19,8 & 46,5 & 18,9 & 12,5 \\
\hline Régiójával & 3,6 & 14,5 & 46,5 & 21,4 & 13,9 \\
\hline Európával & 7 & 18,4 & 31,2 & 27,6 & 15,9 \\
\hline Saját etnikai csoportjával & 24,2 & 33,4 & 17,5 & 4,7 & 20,1 \\
\hline
\end{tabular}

Forrás: Nyíregyházi középiskolások $2015(\mathrm{~N}=359)$

1. táblázat. Mennyire érzi erősnek a kapcsolatát a felsorolt közösségekkel? (százalék)

A 359 diákból 226 fő (63\%-a) fejezte ki, hogy a családdal nagyon erősnek érzi a kapcsolatát, ezt más Nyíregyházán végzett empirikus ifjúsági vizsgálat (R. Fedor 2016) is bizonyítja. A szakirodalommal összevetve azt állapíthatjuk meg, hogy alacsonyabb százalékban jelölték meg erősnek a diákok saját etnikai csoportjával való kötődésüket. A mi vizsgálatunk során a második legnagyobb (24,2\%) nagyon erős kötödéssel rendelkező közösség, és ezt még növeli az, hogy 33,4\%-a a megkérdezetteknek erösnek jelölte meg a kapcsolatot a saját etnikumával. Továbbá a vizsgálat meglepő eredménye az, hogy a megkérdezettek ötöde $(20,1 \%$-a) nem tudott mit kezdeni a kérdéssel, illetve nem akart válaszolni a kérdésre. E témával kapcsolatban határainkon túl Ristić és munkatársai 2013-ban egy temerini (vajdasági) középiskolások körében végzett „hely” és identitás vizsgálatot. Mind a szerb, mind a magyar diákok szemében az etnikai közösséghez tartozás jóval fontosabb, mint az egyéb, etnikailag vegyes közösségekhez (régió, település) való kötődés. A két kutatás eredménye nem összehasonlítható, de párhuzamba vonható és megállapítható a jelen kutatás esetében is, hogy a saját etnikumi csoporthoz tartozás az ifjúság körében fontosabb, mint a lakóhely, megye, régió, ország és Európához való kötődés.

A városával (falujával) való kapcsolat, elégedettség fontos lehet az otthon maradás szempontjából. A megkérdezett fiatalok kis százaléka (7,2\%-a) jelölte meg azt, hogy nagyon erős a kapcsolata a településével, 35,1\%-a erősnek, 40,1\%-a gyengének és 10,3\%-uk egyáltalán nem érez erős kapcsolatot Nyíregyházával, illetve lakóhelyével. Előzetesen azt feltételeztük a szakirodalomra támaszkodva ${ }^{3}$, hogy a diákok kötődése a városhoz erösebb, mint az etnikumhoz és az elvontabb földrajzi fogalomhoz. Az

\footnotetext{
${ }^{3}$ Magyarországon Egedy (1996) végzett empirikus vizsgálatot három városban (Győr, Szarvas és Budapest). Kutatása során első kérdése az volt, hogy elégedett-e a diák a városával. A győri fiatalok döntő többsége (89\%), a szarvasi fiatalok pedig magas arányban (83\%) elégedettek, míg Budapesten inkább megoszlik a diákok véleménye: a megkérdezettek $70 \%$-a válaszolt igent a kérdésre.
} 
eredmény csak részben igazolta a várakozásunkat, ugyanis a nagyon erős és az erős választ adók aránya nem éri el a megkérdezettek felét.

A vizsgálatunk kitért arra kérdésre, hogy a fiatalok mennyire érzik a határmenti megye hatását az életükre. A fiatalok 10,9\%-a érzi, hogy hatással van az életére, 11,1\%-a szerint többnyire hatással van, 29,5\%-a szerint van, amiben hatással, van, amiben nincs, 22,6\%-a szerint többnyire nincs hatással és a megkérdezettek 24,5\%-a egyáltalán nem érzi, hogy hatással van az életére, hogy határmenti megyében él. Megvizsgáltuk, hogy ezeket az arányokat mi magyarázza. Azt tapasztaltuk, hogy a jelenlegi kérdésre adott válaszok esetében nincs szignifikáns eltérés a nemek között, a szülök iskolai végzettsége, a szubjektív anyagi jólét alapján. Viszont az objektív jólét, illetve az, hogy beszéli-e a szomszédos országok valamelyik nyelvét változók között találtunk szignifikáns eltéréseket. Minél jobb anyagi körülmények között él egy fiatal, illetve beszéli a szomszédos ország nyelvét, annál jobban érzi a határmentiség hatását az életére. Továbbá az is megfigyelhető, hogy a szomszédos országokba történő bármilyen célú utazás (bevásárlás, szülők munkavégzése, rokon és barátok, tanulmány folytatás tervezése, letelepedés tervezése, szomszédos nyelvismeret) ugyancsak szignifikáns hatást mutat a határmenti térség hatásának megítélésben. Azok a fiatalok, akik járnak a szomszédos oszág(ok)ba, illetve beszélik ezek közül valamelyik nyelvét, ők inkább érzik, hogy ez a határmenti régió, amelyben élnek, hatással van az életükre.

\section{A nemzetköziség megjelenése az utazási tapaszta- latokban és a jövőtervekben}

Az ifjúság határmenti térségi identitásának, illetve a határmentiség hatásának megismeréséhez fontos feltárni a fiatalok szomszédos országba végzett tevékenységét e tevékenységek gyakoriságát és a szomszédos nemzetekhez való viszonyulását, attitüdjét. A határmentiség jellemzője, hogy határon átnyúló rokoni és baráti kapcsolatok, a munka, tanulás vagy szabadidő-eltöltési célú határátlépés a mindennapok velejárója (Hardi 2008). A nyíregyházi diákok 50,1\%-ának vannak a szomszédos országok egyikében élő barátai, 37,3\%-nak pedig rokonai is. Negyedük jár bevásárolni az egyik szomszédos országba. Szintén magas azok aránya, akik beszélik valamely szomszédos ország nyelvét $(38,4 \%)$, illetve több, mint negyedük tervezi, hogy szomszédos országban fog letelepedni (29,8\%), vagy tanulni (20,3\%) (1. ábra). Ám felvetődik a kérdés, hogy utóbbi három esetben a viszonylag magas arányok mögött nem az húzódik-e meg, hogy németül tanulnak, s Ausztriába terveznek tanulni, letelepedni. Ezt a felvetést erősíti meg a külföldi mobilitással járó jövőtervek elemzése. Mindenesetre erős regionális kötődést lehet detektálni a nyíregyházi diákok körében.

A jövőtervek ismertetése előtt azonban fussuk át azt, hogy milyen utazási tapasztalatokkal és más nemzetekkel kapcsolatos attitüdökkel rendelkeznek a nyíregyházi fiatalok. A megkérdezettek többsége volt már külföldön életében, 6,6\%-a havonta néhányszor, 42,7\%-a évente néhányszor, 39,3\%-a egyszer-kétszer volt már életében és $11,1 \%$-uk még nem járt külföldön. A havonta néhányszor, évente néhányszor és egyszer-kétszer voltam életemben adott válaszokat összevontuk arra, hogy „,volt már külföldön”, valamint külön válaszként kezeltük, hogy „még nem voltam”. A 
„volt már külföldön” válaszadók válaszait megvizsgáltuk, hogy milyen célból voltak külföldön, a leggyakrabban a következő célból: 71,2\%-a turizmus, 5,5\%-a üzleti út, ami alatt áru eladását vagy vételét kell érteni, és 13,7\%-uk rokonok és barátok látogatása céljából. Az utazási tapasztalatokat erősen befolyásolja a családok anyagi helyzete. Az gazdasági helyzetet mérő mindkét tőkemutató szignifikáns összefüggésben van az utazási tapasztalatokkal. Minél magasabb az objektív vagy szubjektív gazdasági tőkéje a családnak, annál gyakrabban volt lehetősége külföldre utazni a válaszadó fiatalnak. Szintén erős az összefüggés a szülők iskolai végzettsége és a külföldi utazások között: mind az anya, mind az apa esetében a legmagasabb iskolai végzettségü szülők gyerekei azok, akik gyakoribb külföldi utazásokról számoltak be, míg az alacsony iskolai végzettségü szülök gyerekei között magasabb azok aránya, akik még sosem jártak külföldön. A család anyagi helyzetével és a szülők iskolázottságával általában együtt járó háttérváltozó, az iskolatípus is szignifikáns összefüggést mutatott a külföldi utazási tapasztalatokkal: a magasabb iskolatípusba (gimnáziumba) járó fiatalokra magasabb arányban jellemző, hogy évente párszor járnak külföldre. Gyengén, de szignifikánsan befolyásolja a nem az utazási tapasztalatot: a fiúk valamivel többször utaztak már életükben, mint a lányok. A településtípus nem befolyásolja a külföldi utazások intenzitását.



Forrás: Nyíregyházi középiskolások 2015 (N=359)

1. ábra. A nyíregyházi fiatalok regionális tapasztalatai és tervei.

A szomszédos és más nemzetekhez füződő attitüdök felmérése során ötfokú sálán fejezhették ki a szimpátiájukat vagy ellenszenvüket a fiatalok. Az 5 a pozitív viszonyulást, az 1 pedig a negatívat jelentette, s a következő átlagokat kaptuk eredményül: a nyíregyházi fiatalok által legpozitívabb megítélt csoportok a német és az amerikai (mindkettő 3,8 átlagponttal, szórás: 0,9 és 1), a lengyel (3,6 átlagpont, szórás: 0,9) és végül a francia (3,5 átlagpont, szórás:1). A kedveltség tekintetében középmezőnybe tartoznak az csehek (3,3 átlagpont, szórás: 0,8), oroszok (3,2 átlagpont, szórás: 1$)$, litvánok és fehéroroszok (3,1 átlagpont, szórás: 0,8). A legnépszerütlenebbek a kör- 
nyező országok: az ukránok és szlovákok (2,9 átlagpont, szórás: 1,1), illetve a románok (2,7 átlagpont, szórás: 1,1). A románok mellett a legnépszerütlenebb csoport a muszlimok (2,7 átlagpont szórás: 1,1) (2. ábra). Az eredmények beilleszkednek más ifjúságkutatások eredményeibe: a környező országok lakói jellemzően a legkevésbé kedveltek, őket követik a más földrészek népei („kongói”, „kínai”), míg a nyugateurópai országok után a legszimpatikusabbak a rokonnak tartott finnek és a határon túli magyarok (Murányi és Szabó 2007, Murányi 2012).

A népcsoportok megítélésben iskolatípus és településtípus tekintetében nincs szignifikáns különbség. A szülők iskolázottságát tekintve az apa legmagasabb iskolai végzettsége négy népcsoport megítélése esetben mutatott szignifikáns összefüggést: a lengyelek, a németek, a fehéroroszok és a csehek esetében is az apa iskolai végzettségének növekedésével együtt nőtt az adott nemzethez tartozók pozitív megítélése. A többi nemzet megítélésben szignifikáns összefüggés nem mutatkozott, de általánosságban is elmondható, hogy minél magasabb az apa iskolai végzettsége, a gyermek annál elfogadóbb más népcsoportokkal szemben. Az édesanya legmagasabb iskolai végzettsége a lengyelek, a németek, a litvánok és a csehek esetében mutatott szignifikáns összefüggést, mind a négy esetben minél magasabb az anya iskolai végzettsége, annál elfogadóbb hozzáállás jellemzi a válaszadót. A nemeket tekintve néhány esetben szintén kimutatható szignifikáns összefüggés: a lengyeleket kivéve a nők kevésbé elöítéletesek az amerikaiakkal, a románokkal, a szlovákokkal, a franciákkal és a muszlim népekkel szemben. Az objektív anyagi helyzet csak két nemzet megítélése esetén bír befolyásoló erővel: a lengyelek és a németek esetében az átlag feletti objektív anyagi tőkével rendelkező családok gyermekei pozitívabban ítélik meg e két nemzethez tartozókat. Ám a szubjektív anyagi helyzettel egyedül a németek megítélése függött össze: az átlag feletti szubjektív anyagi helyzetüek pozitívabban ítélik meg őket. Az eredményeink hasonlóak más, országos ifjúságvizsgálat eredményeihez (Murányi és Szabó 2007).

Azt is megvizsgáltuk, hogy a megkérdezettek nemzetiséghez való viszonyulását befolyásolja-e, hogy beszéli-e vagy nem a szomszédos ország nyelvét, illetve rendelkezik-e vagy nem rokoni, baráti kapcsolatokkal, valamint hogy milyen gyakran ,jár át a szomszédos országokba". Azt az eredményt kaptuk, hogy e tényezők nem befolyásolják a szomszédos nemzetekhez való viszonyulásukat. Továbbá azt is megállapíthatjuk, hogy a diákok a nemzetiségekkel szemben tanúsított attitüdjeik alapján kevésbé elfogadók.

A fiatalok migrációs terveinek egyik speciális szelete az oktatási, felsőoktatási mobilitás. A válaszadóktól megkérdeztük, hogy szeretnének-e továbbtanulni, s amennyiben szeretnének még tanulni a középiskola után, hol tervezik azt. Általánosságban a fiatalok 63,2\%-a szeretne még tanulni, további 20,9\%-uk pedig munka mellett szeretne tanulni. Csupán 10\%-uk vállalna munkát a végzés után, s 5,9\% azok aránya, akik otthon maradnának, vagy még nem tudják, mit fognak tenni végzés után. Ez az eredmény hasonló a 2012-es Magyar Ifjúság Szabolcs-Szatmár megyei almintájához, ahol a válaszadók 41\%-a jelezte, hogy szeretne még tanulni (Szabó és Nagy 2015). A tanulni vágyók döntő többsége $(53,2 \%)$ felsőoktatásban gondolkodik. Korábbi vizsgálatok eredményeit látva (Ruff 2013, Székely és Pitó 2010, Pusztai és Nagy 2005) meglepő módon a külföldi továbbtanulási vágyakat nem befolyásolja a kérdezett neme, szülei iskolai végzettsége, sem a család objektív, sem a szubjektív anyagi helyzete, sem a településtípus. 
Szignifikáns összefüggés egyedül azzal a kérdéssel mutatkozott, hogy a végzés után hol képzeli el a fiatal az életét, hol szeretne letelepedni. Akik a külföldi tanulásban gondolkoznak, azok jellemzően külföldön képzelik el a jövőjüket.

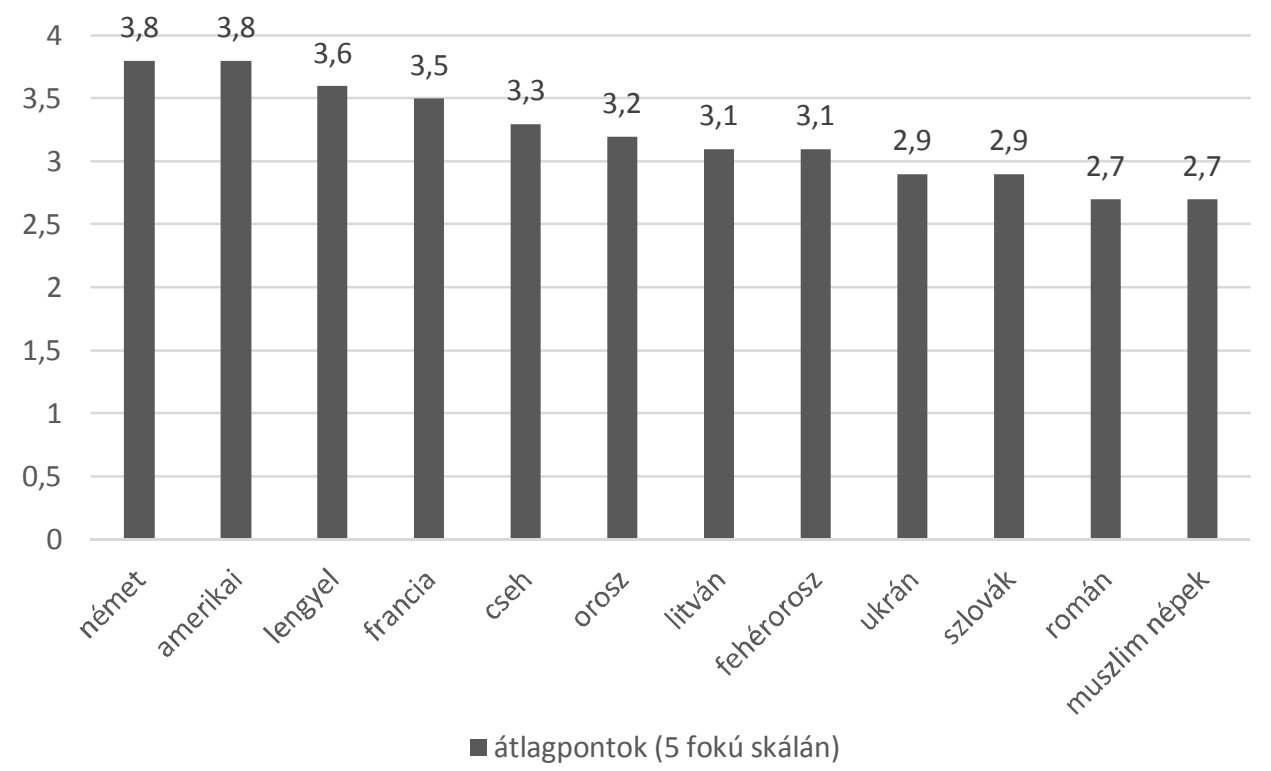

Forrás: Nyíregyházi középiskolások 2015 (N=359)

2. ábra. Társadalmi távolságérzet a felsorolt nemzetekkel szemben (átlagpontok - 5 nagyon pozitív megítélés, 1 nagyon negatív megítélés).

A következő kérdés a tervezett tanulás helyszíne. A válaszkategóriák között szerepelt Nyíregyháza, a megyén belüli másik település, országon belüli másik város és külföld. Csak egy választ lehetett bejelölni, így a válaszadók 39,6\%-a nevezte meg a fóvárost, 24,2\% a megyén kívüli várost (jellemzően Debrecent), 12,8\%-a pedig Nyíregyházát. Ezt követte külföld 5,8\%-kal, majd pedig a megye más városa $(3,1 \%)$. Viszont ha hozzátesszük azokat a fiatalokat is, akik ha egyet kell választani, nem a külföldöt választották, de mégis neveztek meg olyan országot, ahol szívesen tanulnának még a középiskola után, akkor 5,8\%-ról 22\%-ra (79 före) növekszik a külföldi tanulmányokat tervezők aránya. A Nyíregyháza Ifjúsága 2015 kutatás 15-18 év közötti almintájában ez az arány 42,2\% volt (Kállai et al., 2016). A konkrétan megnevezett országokat tekintve Anglia a legnépszerübb (a külföldi tanulmányokat dédelgetők 34,2\%-a nevezte meg) azt követi az Amerikai Egyesült Államok (19\%-kal), Ausztria $(11,4 \%)$ és Dánia $(8,9 \%)$. A külföldre tanulni vágyakozó fiatalok egy része $(12,7$ százalékuk) viszont nem nevezett meg konkrét célországot. Egy-két válaszadó által megnevezett ország volt még Franciaország, Hollandia, Norvégia, Új-Zéland, Japán, DélAfrikai Köztársaság, Románia, és meglepő alacsony említési aránnyal Németország. Országos migrációs tendenciák szerint a legnépszerübb célországok Németország, 
Egyesült Királyság és Ausztria (Blaskó és Gödri 2014), a felsőoktatási tanulás célországai között az elöbbiek mellett nagyobb arányban megjelenik Franciaország, Olaszország is (Kiss 2014, Dusa 2015).

A külföldi tanulmányok vállalásának motivációira vonatkozó többválasztós kérdéssor alapján azt látjuk, hogy a legjellemzőbb indoka a külföldi tanulási terveknek a kalandvágy (,világot szeretnék látni” - 91 említés), illetve a jobb élet reménye (,a tanulmányok befejeztével könnyebb munkát vállalni, karriert építeni” - 76 említés; „ott magasabb az életszínvonal” - 73 említés; „,magasabb szintü, minőségü az oktatás” - 47 említés). Legkevésbé a felszerelt laboratórium, könyvtár; a biztonságos helyszín és a közelség a motiváló cél (lásd 2. táblázat). A Magyar Ifjúság 2012-es adatfelvétele során általánosságban (nem a tanulásra vonatkoztatva) vizsgálták a tervezett mobilitás mozgatórugóit, de ott is a jobb megélhetés, tapasztalatszerzés, karrierépítés állt leginkább a motivációk hátterében (Ruff 2013).

\begin{tabular}{|l|c|}
\hline „Miért szeretne külföldön tanulni?" & $\begin{array}{c}\text { Említések száma } \\
\text { összesen }\end{array}$ \\
\hline Világot szeretnék látni & 91 \\
\hline $\begin{array}{l}\text { A tanulmányok befejeztével könnyebb munkát vállalni, karriert } \\
\text { épini }\end{array}$ & 76 \\
\hline Ott magasabb az életszínvonal & 73 \\
\hline A magasabb szintü, minőségű oktatás miatt & 47 \\
\hline $\begin{array}{l}\text { Mozgalmas az élet, lehetőség van érdekesen eltölteni a szabad- } \\
\text { idöt }\end{array}$ & 43 \\
\hline Könnyebb az önmegvalósítás, a képességeim fejlesztése & 42 \\
\hline Könnyebben lehetek független, önálló & 39 \\
\hline Külföldi diploma megszerzése miatt & 34 \\
\hline $\begin{array}{l}\text { A külföldi tanulmányok nagyobb lehetőséget adnak az áttelepü- } \\
\text { lésre }\end{array}$ & 28 \\
\hline Ott van demokrácia és szólásszabadság & 14 \\
\hline Nincs korrupció az oktatásban & 11 \\
\hline Egyéb & 11 \\
\hline Ott jobban felszereltek a laboratóriumok, könyvtárak & 5 \\
\hline Ott biztonságosabb, távol van a háborús konfliktusoktól & 4 \\
\hline $\begin{array}{l}\text { Ott olyan felsőoktatási intézmény van, ami közel van a lakhe- } \\
\text { lyemhez }\end{array}$ & 3 \\
\hline
\end{tabular}

Forrás: Nyíregyházi középiskolások 2015 (N=359)

2. számú táblázat. A külföldi tanulás motiváló okai (említések száma).

Általánosságban is rákérdeztünk arra, hogy a fiatalok jövőtervében megjelenik-e a migráció, tervezik-e, hogy külföldön élnek majd. Erről árulkodik az a kérdés, mely arra vonatkozott, hogy mit gondol a válaszadó, a középiskola elvégzése után hol fog élni. A fiatalok csak egy válaszkategóriát választhattak a kilenc lehetőség közül. 11,7 százalékuk ott képzeli el a jövőjét, ahol most is él, további 3,9 százalék a megyéjén belül, de másik településen. 17 százalékuk az ország egy másik megyéjének településén tudja elképzelni az életét végzés után, míg 14,5 százalék a fővárosba szeretne költözni. 24 százalék még nem tudja, vagy nem akart válaszolni a kérdésre, ám 29 százalékuk külföldön szeretne élni, dolgozni. Tehát azt látjuk, hogy míg a középiskolát 
követő külföldi tanulmányok tervezése nem annyira markánsan jellemző a fiatalokra, addig a jövőtervekben mégis megjelenik a migráció, $s$ a válaszadó fiatalok több mint negyede szeretne külföldön élni. A „Nyíregyháza Ifjúsága 2015” kutatás szerint a 1518 éves korcsoport 35\%-a tudja elképzelni, hogy akár véglegesen külföldre települ, további $47 \%$ ha nem is örökre, de kipróbálná magát külföldön (Kállai et al. 2016). Vizsgálatunkban a jövőtervekre csak a válaszadó neme és településtípusa van hatással. Inkább a lányokra jellemző, hogy nagyobb arányban gondolkodnak abban, hogy elhagyják a megyéjüket, s másik magyarországi városban élnek majd a jövőben. Szintén a lányok és a nagyvárosban élök tervezik nagyobb arányban, hogy külföldön fognak letelepedni.

\section{A nyíregyházi fiatalok életmódjának és jóllétének néhány aspektusa}

A tanulmány utolsó részében arra keressük a választ, hogy individuális szinten milyen vonások jellemzik a nyíregyházi középiskolásokat: mit csinálnak szabadidejükben, milyen mintázatok rajzolódnak ki, s vajon mennyire jellemzi őket magányos, vagy éppen társas szabadidő-eltöltés. Továbbá arra is kíváncsiak vagyunk, hogy összességében mennyire elégedettek életükkel, hogyan függnek ezek a dimenziók össze, s mely szocio-kulturális tényezők befolyásolják ezeket a kérdéseket.

A nyíregyházi középiskolások szabadidő-eltöltése teljes mértékben belesimul az országos trendekbe: tulajdonképpen ők is screenagereknek tekinthetők (Horkai 2002), akik elsősorban egyedül, otthon, digitális közegben zajló tevékenységekkel foglalkoznak, mint ahogy a magyar fiatalok általánosságban (Huszti és Takács 2016, Nagy 2013). Naponta 70,3\%-uk chatel, 69,9\% hallgat zenét, minden ötödik fiatal játszik számítógépes játékot, de a passzív pihenést is minden második fiatal választja napi kikapcsolódásként. Örvendetes, hogy a fiatalok 38,8\%-a, sportol, 38,7\%-sétál, 14,2\%a játszik sportos játékokat hetente többször is. Korábbi, nyíregyházi fiatalok körében végzett vizsgálatunkban is igazoltuk, hogy a középiskolások körében még igen magas (mintegy 70\%) a sportolók aránya, de a középiskola befejeztével egy drasztikus csökkenés tapasztalható e téren (Kovács 2016). A társas, szórakozáshoz kapcsolódó tevékenységek közül 44,6\% jár havonta többször diszkóba, 38,4\% kávézóba, bárokba, minden harmadik billiárdozni, bowlingozni, moziba. A kötelezőn kívüli tanulás is fontos szerepet játszik a fiatalok életében, hiszen egyharmaduk nyilatkozott úgy, hogy naponta végez valamilyen önképzéshez kapcsolódó tevékenységet, 37,3\% pedig szívesen tanul idegen nyelveket. Ugyanakkor a tv-nézés egyre kevésbé játszik szerepet a fiatalok életében: 36,5\%-uk néz naponta tévét. A legnépszerübb müsorok a filmek (16,7\% nyilatkozott úgy, hogy leginkább ezt néz tévézéskor), ezt követik a szórakoztató müsorok, játékok, vetélkedők, majd pedig a sportmüsorok. A legkevésbé kedveltek a klipek, üzleti információk és politikai müsorok.

Gyakorlatilag soha nem vesz részt képzőmüvészeti körön a középiskolások 69,9\%a, nem sakkozik kétharmaduk, nem jár templomba 57,4\%, és nem végez müszaki, technikai tevékenységek 59,6\%. Soha nem jár koncertekre a válaszadók egyharmada, színházba egynegyede, s nem olvas szépirodalmat 22,8\%. Mindezek az arányok pedig 
jól mutatják, hogy mennyire másképpen tölti szabadidejét ez, az ún. Z- és majdnem $\alpha$-generáció, mint például szüleik generációja. Az egyes tevékenységek végzésének gyakoriságát az alábbi 3. ábra mutatja.

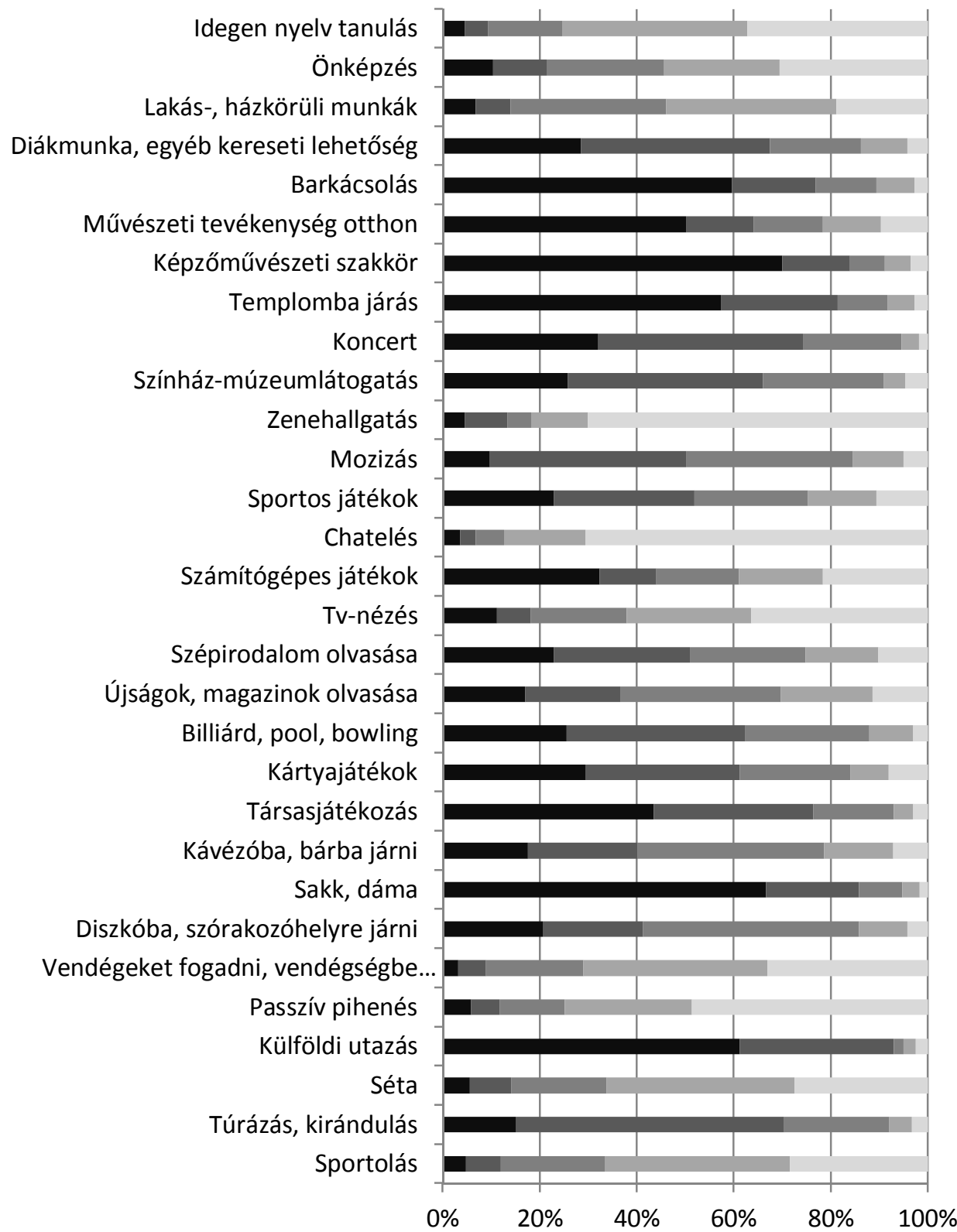

घyakorlatilag soha घÉvente többször $\quad$ Havonta többször

- Hetente többször Naponta

Forrás: Nyíregyházi középiskolások 2015 (N=359).

3. ábra. Az egyes szabadidős tevékenységek végzésének gyakorisága. 
Adatredukció érdekében faktorelemzéssel nyolc szabadidő-eltöltési preferenciát különböztettünk meg. ${ }^{4}$ A társas tevékenységekhez tartoznak a koncertek, szórakozóhelyek látogatása, sportos játékok, mozizás, a rekreációhoz a passzív pihenés, chatelés, zenehallgatás, míg a kultúra-fogyasztásba a színház-, múzeumok látogatása, szépirodalom olvasása. A tanulás faktorába tartozik az önképzés, idegen nyelvek tanulása, de a sportolás is, úgy tünik, ilyen tanulási folyamatnak tekinthető. Az aktív szabadidőeltöltés faktorát a különféle müvészeti tevékenységek, diákmunka és templomba járás alkotják. A tv-nézés, újságolvasás és vendégjárás változók alkotják az informálódás faktorát, míg a játékok faktorát a különféle társas- és számítógépes játékok. Az utolsó, „, hang out”szabadidős preferenciába a városi séta, kávézók, bárok látogatása és a kirándulás tartozik, ami arra utal, hogy az ilyen szabadidő-eltöltési típusba tartozó fiatalok leginkább abban lelik örömüket, ha nincsenek otthon. A faktorsúlyokat 0-tól 100-ig tartó skálává alakítottuk át ( 0 jelenti, ha egy szabadidős preferencia egyáltalán nem, 100 pedig, ha teljes mértékben jellemez egy válaszadót), s megnéztük az átlagpontszámokat: a társas preferenciában 34 , 1, a rekreatívban 69,6, a kultúrafogyasztóban 47,9, a tanulásban 39,4, az aktívban 54,7, az informálódóban 57,7, a játékokban 25,4, a 'hang out'-ban pedig 45, 3 pontot értek el a válaszadók.

A továbbiakban azt nézzük meg, hogy mely szocio-kulturális tényezők befolyásolják az egyes preferenciákat, milyen különbségeket találhatunk, nemek, anyagi helyzet, településtípus és a szülők iskolai végzettsége mentén (3. táblázat). Ha nemek szerint vizsgáljuk a különbségeket, akkor azt láthatjuk, hogy egyedül a tanulás-orientált faktorban nincs különbség: a férfiakra inkább jellemző a társas, kultúrafogyasztó, aktív, játékos, „hang out” szabadidő-töltés, míg a nőkre inkább a rekreatív és informálódó preferenciák. Ezek a preferenciák teljes mértékben összhangban vannak a hagyományos nemi szerepekkel. Az aktív szabadidő-eltöltés leginkább a kisvárosiakra és legkevésbé a falusiakra jellemző, ami a lehetőségek hiányára vezethető vissza ez utóbbi esetekben, de az informálódás, vendégjárás fontossága is meglepő módon kevésbé jellemzi a községből származókat. A szubjektív és objektív anyagi helyzetnek, valamint mindkét szülő iskola végzettségének is a társas szabadidő-eltöltési preferenciában van szerepe, az átlag felettiek és a felsőfokú végzettséggel bíró szülők gyerekei ez esetben is előnyben vannak, hiszen ahhoz, hogy egy szórakozóhelyen igényeiknek megfelelően tudjanak fogyasztani, moziba, koncertekre menni, bizony olykor nem kis összegre van szükség, fóleg, ha ezt társaságban teszik. Az apa iskola végzettségének mint kulturális tőkének az aktív szabadidős preferenciában is szerepe van: de nagyon érdekes, hogy a tanulás az alacsony iskolai végzettségü szülők gyerekeire jellemző a leginkább. Ebben az játszhat szerepet, hogy számukra több idővel jár a kötelező tanulmányi feladatok elvégzése, s ebben a szülők hátrányaik miatt kevésbé tudnak segíteni, ugyanakkor óvatosan kell kezelni ezt az eredményt az alacsony elemszám miatt. Azt is láthatjuk, hogy a felsőfokú apák nagyobb hangsúlyt fektetnek, hogy gyerekeik aktívan, tehát valamiféle alkotó, közösségi tevékenységgel töltsék szabadidejüket. A szakirodalommal összhangban van az, hogy a magas-kultúrafogyasztás, ami egyfajta elit tevékenységnek tekinthető, szintén a (jelen esetben objektíve mért) jobb anyagi helyzetben lévők kiváltsága (Nagy 2013, Kovács 2012, 2016, Bocsi 2014).

\footnotetext{
${ }^{4}$ Principal Components, Direct oblimin rotációval. KMO értéke 0,811, a magyarázott variancia értéke $56,1 \%$.
} 


\begin{tabular}{|c|c|c|c|c|c|c|c|c|c|c|}
\hline & & Társas & Rekreatív & $\begin{array}{l}\text { Kultúra- } \\
\text { fogyasztó }\end{array}$ & $\begin{array}{l}\text { Tanulás- } \\
\text { orientált }\end{array}$ & Aktív & $\begin{array}{l}\text { Informá- } \\
\text { lódó }\end{array}$ & Játékos & Útkereső & $\mathrm{n}$ \\
\hline \multirow[t]{2}{*}{ Nem } & Nő & $31,9 *$ & $72,1^{*}$ & $43,9 *$ & 38,6 & $52,2 *$ & $60,3^{*}$ & $29,9 *$ & $42,4^{*}$ & 194 \\
\hline & Férfi & $37 *$ & $67,5^{*}$ & $53,8^{*}$ & 39,5 & $57,8^{*}$ & $55,4^{*}$ & $41,5^{*}$ & $49,1^{*}$ & 147 \\
\hline \multirow[t]{4}{*}{ Lakóhely } & $\begin{array}{l}\text { Nagy } \\
\text { város }\end{array}$ & 36,8 & 73,5 & 47,9 & 41,1 & $52,3^{*}$ & $64,9 *$ & 33,3 & 46,4 & 43 \\
\hline & $\begin{array}{c}\text { Közepes } \\
\text { város }\end{array}$ & 35,4 & 71,5 & 48,8 & 38,1 & $55,2^{*}$ & $59,1 *$ & 35,7 & 44,4 & 65 \\
\hline & Kisváros & 32,6 & 69,5 & 49 & 39,1 & $57 *$ & $58,4^{*}$ & 35 & 45,2 & 136 \\
\hline & falu/tanya & 33,6 & 68,2 & 46,4 & 38,7 & $51,2 *$ & $54,5^{*}$ & 35,9 & 44,4 & 92 \\
\hline \multirow{2}{*}{$\begin{array}{c}\text { Szubjektív } \\
\text { anyagi } \\
\text { helyzet }\end{array}$} & $\begin{array}{l}\text { Átlag } \\
\text { alatt }\end{array}$ & $30,5^{*}$ & 68,2 & 47,4 & 40,8 & 53,3 & 56 & 34,4 & 45,4 & 171 \\
\hline & $\begin{array}{c}\text { Átlag fe- } \\
\text { lett }\end{array}$ & $36,6^{*}$ & 71,3 & 48,5 & 37,7 & 56,5 & 59,6 & 35,4 & 45,5 & 167 \\
\hline \multirow{2}{*}{$\begin{array}{c}\text { Objektív } \\
\text { anyagi } \\
\text { helyzet }\end{array}$} & $\begin{array}{l}\text { Átlag } \\
\text { alatt }\end{array}$ & $30,4^{*}$ & 68 & $45,4^{*}$ & 41,5 & 53,6 & 55,8 & 33,8 & 44,9 & 145 \\
\hline & $\begin{array}{l}\text { Átlag } \\
\text { felett }\end{array}$ & $36,8^{*}$ & 71 & $49,4^{*}$ & 37,8 & 55,3 & 59,1 & 36,5 & 45,6 & 206 \\
\hline \multirow{3}{*}{$\begin{array}{c}\text { Anya isko- } \\
\text { lai végzett- } \\
\text { sége }\end{array}$} & Alap & $33,9 *$ & 64,2 & 47,8 & 44,4 & 57,5 & 58,2 & 34,7 & 43,5 & 25 \\
\hline & Közép & $32 *$ & 69,8 & 47,4 & 39,9 & 54,3 & 58,8 & 33,4 & 46,4 & 190 \\
\hline & Felső & $37,5^{*}$ & 71,4 & 49,6 & 36,5 & 54,7 & 57,2 & 37,4 & 43,7 & 122 \\
\hline \multirow{3}{*}{$\begin{array}{c}\text { Apa iskolai } \\
\text { végzett- } \\
\text { sége }\end{array}$} & Alap & $31,6^{*}$ & 63,9 & 50,4 & $48,5^{*}$ & $53,1^{*}$ & 55,4 & 33,3 & 47,1 & 31 \\
\hline & Közép & $33,2 *$ & 70,4 & 48,5 & $39,2 *$ & $53,3^{*}$ & 59,3 & 34,1 & 44,7 & 204 \\
\hline & Felső & $37,1^{*}$ & 70,7 & 46,9 & $36,2^{*}$ & $58,1^{*}$ & 55,7 & 37,2 & 45,5 & 100 \\
\hline
\end{tabular}

${ }^{*} \mathrm{p} \leq 0,05$

Forrás: Nyíregyházi középiskolások 2015.

3. táblázat. A szabadidős-preferenciák faktorainak átlagpontszámai a társadalmi háttérváltozók mentén (pontok).

A kutatásban az életminőség és szubjektív jóllét egyik legfontosabb összetevőjét, az élettel való elégedettséget mértük (Ryan és Deci 2001, Diener et al. 1985), amely társadalmi szinten is fontos indikátora a fiatalok mentális állapotának, hiszen az elégedetlenebbek rosszabbnak ítélik egészségi állapotukat, inkább nyúlnak egészségkárosító szerekhez, komoly rizikótényezője a mentális, pszichikai problémáknak (Székely, Susánszky és Ádám 2013). A fiatalok döntő többsége $(57,1 \%)$ inkább elégedett az életével, minden negyedik fiatal pedig nagyon elégedett (24\%), s mindössze 14,2\%uk mondta azt, hogy valamelyest nem elégedett, az átlagpontszám pedig 67 pont volt a 0-tól 100-ig tartó skálán. Szinte alig van különbég nemek szerint, így nem igazoldódott a korábbi eredményekben tapasztalt tendencia, hogy a férfiak elégedettebbek. Sem a településtípusnak, sem az apa iskolai végzettségének nincs hatása, viszont az anyáénak igen: a felsőfokú végzettséggel bíró anyák gyermekei 72 pontot értek el az 
élettel való elégedettség skálán, míg a középfokú és alapfokú végzettséggel bíró anyák gyerekei 6, illetve 12 ponttal értek el kevesebbet. Ez az eredmény nagy valószínüséggel az iskolai végzettség összefüggésével magyarázható a társadalmi, anyagi helyzettel. Ezt igazolja az a tény, hogy mind az objektíve, de leginkább szubjektíve mért átlagnál jobb anyagi helyzetben lévő fiatalok lényegesebben elégedettebbek életükkel (70,7 és 76,4), mint az átlag alattiak (63,8 és 59,8 pont). Hasonlóképpen a legmagasabb beosztásban és presztízsü szakmákban dolgozó szülők (igazgatók, cégtulajdonosok, mérnökök) gyermekei érték el a legmagasabb pontszámot (apa: 77, 80,7 és 68,5; anya: 74,2, 76,4 és 72,8 pont), ami összefüggésben áll a szülök magasabb iskolázottságával és jövedelmével. A legalacsonyabb pontszámokat a betanított segédmunkások gyerekei érték el (apa: 50,9; anya: 48,3), emellett az apák esetében még az alsóbb szintü hivatalnokok $(52,8)$, az anyáknál pedig a munkanélküliek gyermekei $(54,8$ pont) a legelégedetlenebbek az életükkel. Ez utóbbi esetben az anya munkanélküli státuszából fakadó létbizonytalanság és esetleges anyagi nehézségek okozhatják azt, hogy a gyerekük is elégedetlenebb az életkörülményeivel. A beosztásra vonatkozó eredményeket azonban óvatosan kell kezelni, mivel az egyes kategóriák elemszáma nagyon kicsi. Ki kell emelnünk azt, hogy a szubjektíven megítélt anyagi helyzet nagyobb befolyásoló erővel bír, mint az objektív, különféle anyagi javak léte. A Spearman-féle korreláció is ezt igazolja: a legerősebb együttjárást a szubjektív anyagi helyzettel találtuk $\left(\mathrm{r}_{\text {Spearman }}=0,362 * *\right),{ }^{5}$ majd ezt követi az objektív anyagi helyzet $\left(\mathrm{r}_{\text {Spearman }}=0,164 * *\right)$ és az anya iskolai végzettsége $\left(\mathrm{r}_{\text {Spearman }}=0,144 * *\right)$.

Kutatásunkban megvizsgáltuk azt is, hogy vajon mely szabadidős preferenciák járnak együtt az élettel való elégedettséggel. Azt láthatjuk, hogy két preferencia korrelál ezzel: minél inkább jellemző a társas, bulizós szabadidő-eltöltés egy fiatalra, annál elégedettebb az életével, azonban a tanulás-orientált szabadidő-eltöltés csökkenti ennek szintjét. Korábbi, a régió hallgatói körében végzett elemzéseinkhez hasonlóan (Kovács 2015) azt láthatjuk, hogy a társas tevékenységek, a barátokkal együtt töltött idő nagyon fontos szerepet játszik a középiskolások életében, s noha az egyedül, elsősorban digitális eszközökhöz kapcsolódó szabadidö-eltöltés mindennapi életük szerves részét képezi, a barátokkal vagy bulizással töltött idő életminőségüket, jóllétüket is meghatározza $\left(\mathrm{r}_{\text {Spearman }}=0,195^{* *}\right)$. Azonban a tanulásra fordított pluszidőt tehernek érzik, s rontja a diákok életminőségét $\left(\mathrm{r}_{\text {Spearman }}=-0,167^{* *}\right)$.

\section{Összegzés}

A 2015-ben 11. évfolyamos nyíregyházi diákok $(\mathrm{N}=359)$ körében végzett kérdőíves felmérésünk adatainak elemzése rávilágít a nyíregyházi fiatalok regionális, lokális identitására, külföldi tapasztalataira, terveire, mobilitás vágyára, valamint a szabadidős mintázatára és az élettel való elégedettségére.

A kutatás alapján megállapíthatjuk, hogy a lokalitásnak nagy szerepe van a fiatalok identitáskonstrukciójában. A saját régiójukkal, megyéjükkel, az országukkal gyengé-

$5 * * \mathrm{p} \leq 0,001$ 
nek ítélik meg a kötödésüket, ugyanakkor a vizsgálat arra is rámutat, hogy a megkérdezett diákokat a családjukhoz füzi a legerösebb kötelék és a lokalitáshoz nem füzi erősebb kötelék, mint a saját etnikai csoportjukhoz. Meglepő eredmény, hogy a megkérdezettek szomszédos országokkal lévő kapcsolata nem befolyásolja a szomszédos nemzethez füző viszonyulásukat, holott a nyíregyházi diákok erős regionális kötődését jelzi, hogy a szomszédos országokban sok barátjuk, rokonuk él, gyakran járnak a szomszédos országokba. Általánosságban az utazási tapasztalatokat tekintve azt látjuk, hogy a szakirodalomban jellegzetes mintázatok rajzolódtak ki a nyíregyházi középiskolások mintájában is: a magasabb szocio-ökonómiai státuszú fiatalok jártak már többször külföldön. A más népek iránti attitüdjeik, s a preferencia-sorrend is hasonló, mint a korábbi országos ifjúságvizsgálatokban. A társadalmi-távolság érzését befolyásolja a szülők iskolai végzettsége, s a család gazdasági helyzete is: a jobb helyzetü családok gyermekei pozitívabban vélekednek más nemzetekről. A nyíregyházi fiatalok nemzetközi mobilitási tervei hasonló trendeket mutatnak, mint más magyarországi vagy regionális ifjúságkutatások. A markánsan megfogalmazódó tanulási tervek alacsonyak, azonban a külföldi migrációs tervek (munkavállalási, letelepedési céllal) már magasabb arányban megjelennek, viszont a mobilitási tervek mögött meghúzódó háttérváltozók nem egyértelmúek.

A globalizáció, lokalizáció megjelenését a fiatalok életében fontosnak tartottuk kiegészíteni néhány individualizációs elem vizsgálatával, így megnéztük a nyíregyházi fiatalok életmódjának és életminőségének egy-egy szegmensét, a szabadidős preferenciákat és az élettel való elégedettséget arra helyezve a hangsúlyt, hogy mennyire játszanak szerepet az individuális tevékenységek és a társadalmi háttérváltozók ezekben. Jól látható, hogy egyfajta társas magány jellemző fiataljainkra, mert leginkább chatelnek szabadidejükben, ugyanakkor a bulizással, társas tevékenységekkel mintegy kompenzálják az egyedüllétet, hiszen ezek szintén fontos szabadidős tevékenységek. Ez utóbbi azonban a leginkább társadalmilag determinált: a jobb szocio-kulturális helyzetben lévő családok gyerekei engedhetik meg jobban maguknak, hogy bulizzanak, vagy éppen moziba, koncertekre menjenek. Ha az élettel való elégedettséget mint a szubjektív jóllét egy nagyon fontos elemét vizsgáljuk, szintén azt láthatjuk, hogy leginkább a család szubjektív anyagi helyzete befolyásolja ennek mértékét az objektív mellett: minél jobbnak ítéli meg egy fiatal társadalmi helyzetét, annál elégedettebb életével. Ebben azonban olyan közvetítő tényezők is szerepet játszanak, mint a szülök foglalkozása és beosztása, hiszen a magasabb beosztással járó magasabb társadalmi helyzet szintén hozzájárul középiskolásaink élettel való elégedettségéhez, akárcsak a társadalmilag szintén erősen determinált társas tevékenységek.

\section{Hivatkozott irodalom}

1. Blaskó Zs., Gödri I. (2014). Kivándorlás Magyarországról. Szelekció és célország-választás az „új migránsok” körében. Demográfia 57. (4.) 271-307.

2. Bocsi V. (2013). Az idő a campusokon. Szeged: Belvedere Meridionale.

3. Bocsi V. (2014). Leisure Time atCampuses: Edification of a Focus Group Examination. In: Budzowski, K.; Láczay, M. (eds.), Poland, Hungary, the World. 
Selected Aspects of Contemporary Economy, Culture and Science (21-30). Krakow: Oficyna Widawnicza Politechniki Wroclawskiej.

4. Diener, E., Emmons, R. A., Larsen, R. J., Griffin, Sh. (1985). The Satisfaction With Life Scale. Journal of Personality Assessment 49 (1), 71-75.

5. Dusa Á. R. (2015). Pedagógushallgatók nemzetközi tanulmányi mobilitási tervei. In: Pusztai, G.; Ceglédi, T. (eds.), Szakmai szocializáció a felsőoktatásban (224241). Nagyvárad - Debrecen: Partium Press, Persional Problems Solution, Új Mandátum Kiadó.

6. Egedy T. (1996). A város és az ifjúság - Budapest, Győr és Szarvas a fiatalok szemével. Tér és Társadalom 10 (2-3). 43-54.

7. Hardi T. (2008). A határtérség térszerkezeti jellemzői. Tér és Társadalom 22 (3). 3-25.

8. Horkai A. (2002). Screenagerek. Kvalitatív kutatás a középiskolások körében. Educatio, 11(1), 153-158.

9. Huszti É., Takács P. (2016). Médiahasználat a nyíregyházi ifjúság (15-29 évesek) körében. Új eszközök - új generáció? Acta Medicinae et Sociologica7 (20- 21), 82-111. DOI: 10.19055/ams.2016.7/20-21/5

10. Huszti É., Takács P., Hüse, L. (2016). A „Nyíregyháza Ifjúsága 2015” kutatás módszertana. Acta Medicinae et Sociologica 7 (20-21), 211-218. DOI: 10.19055/ams.2016.7/20-21/11

11. Ilyés Z. (2004). A határforgalom változó tartalmai a geográfiától az empirikus kultúra kutatásig. In: Kovács, N. et al (eds.), Tér és terep. Tanulmányok az etnicitás és az identitás kérdésköréből III. (9-15). Budapest: Akadémia Kiadó.

12. Kállai B., Lengyelné Pogácsás M., Nyírcsák J. (2016): Munkaerö-piac, külföldi munka és tanulás. Acta Medicinae et Sociologica 7 (20-21), 48-81. DOI: 10.19055/ams.2016.7/20-21/4

13. Kiss L. (2014). A tanulmányi célú nemzetközi hallgatói mobilitás alakulása Magyarországon. In: Veroszta, Zs. (ed.), A mozgás tere: A magyar felsőoktatás és a nemzetközi mobilitási folyamatok. Budapest: Balassi Intézet.

14. Kovács K. (2012). Szabadidő és Sport a Debreceni Egyetemen. In: Dusa Á. R., Kovács K., Nyüsti Sz., Márkus Zs., Sőrés A. (eds.), Egyetemi élethelyzetek. Ifjúságszociológiai tanulmányok II (209-232). Debrecen: Debreceni Egyetemi Kiadó.

15. Kovács K. (2015). Teacher education Students' Leisure Activities and State of Health. In: Pusztai G., Ceglédi T. (eds.), Professional calling in higher education (129-138). Nagyvárad - Debrecen: Partium Press, Persional Problems Solution, Új Mandátum Kiadó.

16. Kovács K. (2016). Szabadidő-eltöltés és sportolás a nyíregyházi fiatalok körében. Acta Medicina et Sociologicae 7 (20-21), 112-130. DOI 10.19055/ams.2016.7/20-21/6

17. Ludescher G. (2009). Kistérség és identitástudat. Egy kutatás tapasztalatai. Területfejlesztés és innováció 3 (4). 23-28.

18. Murányi I., Szoboszlai Zs. (2000). Identitás - jellemzők a dél-alföldi régióban. Tér és társadalom 14 (1). 27-49.

19. Murányi I., Szabó I. (2007). Középiskolások elöítéletességének egy lehetséges magyarázata: az életforma. Educatio (1). 38-49. 
20. Murányi I. (2012). Elöítéletesség és demokrácia-értelmezés a fiatalok körében. Educatio (2). 259-271.

21. Nagy Á. (2013). Szabadidős tervek és tevékenységek. In: Székely L. (ed.), Magyar Ifjúság 2012 (211-228). Budapest: Kutatópont.

22. Nagy Á., Székely L. (eds.). (2013). Másodkézből. Magyar Ifjúság 2012. Budapest: Kutatópont.

23. Nárai M. (2009). Gondolatok a regionális identitásról - identitáselemek a nyugatdunántúli régióban. Tér és Társadalom 23 (4). 137-159.

24. Paasi, A. (1989). A régiók fejlődése és a regionális identitás kialakulása. Tér és társadalom 3 (3). 70-79.

25. Palkó K. (2009). Mesterségesen létrehozott területi egység - regionális identitás (?) Burgerland példája. Tér és társadalom 23 (4). 207-224.

26. Pusztai G., Nagy É. (2005). Tanulmányi célú mobilitás Magyarország keleti határvidékein. Educatio (2). 360-384.

27. R. Fedor A. (2016). Családalapítás és gyermekvállalás a fiatalok körében. Acta Medicinae et sociologica 7 (20-21). 11-28. DOI: 10.19055/ams.2016.7/20-21/2

28. Ristić, D. Nagy I., Kicošev, S. (2013). „Hely” és identitás. Egy temerini középiskolások körében végzett vizsgálat tanulságai. Tér és Társadalom 27 (2). 159-170.

29. Ryan, R. M., Deci, E. L. (2001). On Happiness and Human Potentials: A Review of Research on Hedonic and Eudaimonic Well-Being. Annual Review of Psychology 52 (1), 141-166.

30. Ruff, T. (2013). Ifjúsági mobilitás: hajlandóság, lehetőségek és tervek. In: Székely L. (ed.), Magyar Ifjúság 2012 (152-178). Budapest: Kutatópont.

31. Somlyódiné Pfeil E. (2007). Mozaikok a regionális identitás értelmezéséhez. Tér és Társadalom 21. (4). 57-71.

32. Strassoldo, R. (1990): The social construction and sociologic alanalysis of space. In: Hamm, B.; Jalowiecki, B. (eds.), The social nature of space. Warszawa: Polish Academy of Sciences, Committee for Space Economy and Regional Planning, 19-49.

33. Süli-Zakar I. (2010): A Partium régió esélyei a csatlakozás után. In: Juhász, E. (ed.), Régió és oktatás V. Harmadfokú képzés, felnőttképzés és regionalizmus. Debrecen: Center for Higher Education Research and Development (CHERD). 15-24.

34. Szabó F., Nagy Z. É. (2015). Észak-Alföld - Regionális Ifjúsági Helyzetelemzés. In Nagy Á., Székely L. (eds.). Harmadrészt. Magyar Ifjúság 2012. Regionális helyzetelemzések. Budapest: ISZT Alapítvány - UISZ Alapítvány - Excenter Kutatóközpont. 117-149.

35. Székely A., Susánszky É., Ádám Sz. (2013). Fiatalok kockázati magatartása. In: Székely L. (ed.), Magyar Ifjúság 2012. Budapest: Kutatópont. 179-210.

36. Székely L., Pitó K. (2010). Nélkülük megy a vonat tovább? Új Ifjúsági Szemle 8. (2). 38-62. 